\title{
Correction: Amine-borane complex-initiated $\mathrm{SF}_{5} \mathrm{Cl}$ radical addition on alkenes and alkynes
}

\author{
Audrey Gilbert ${ }^{1}$, Pauline Langowski ${ }^{1}$, Marine Delgado ${ }^{2}$, Laurent Chabaud ${ }^{2}$, \\ Mathieu Pucheault ${ }^{* 2}$ and Jean-François Paquin ${ }^{* 1}$
}

\section{Correction}

Address:

1Départment de chimie, Université Laval, Québec, QC, G1V 0A6,

Canada and ${ }^{2}$ Institut des Sciences Moléculaires - Groupe ORGA -

UMR 5255, Université de Bordeaux, 351 Cours de la libération, 33405

Talence, France

Email:

Mathieu Pucheault ${ }^{\star}$ - mathieu.pucheault@u-bordeaux.fr;

Jean-François Paquin ${ }^{*}$ - Jean-Francois.Paquin@chm.ulaval.ca

* Corresponding author

Keywords:

amine-borane complex; pentafluorosulfanyl chloride;

pentafluorosulfanyl substituent; radical addition; radical initiation

\author{
Beilstein J. Org. Chem. 2021, 17, 1725-1726. \\ https://doi.org/10.3762/bjoc. 17.120 \\ Received: 08 July 2021 \\ Accepted: 16 July 2021 \\ Published: 23 July 2021 \\ Guest Editor: D. O'Hagan \\ (c) 2021 Gilbert et al.; licensee Beilstein-Institut. \\ License and terms: see end of document.
}

This correction refers to Beilstein J. Org. Chem. 2020, 16, 3069-3077. doi:10.3762/bjoc.16.256

The stereochemistry of some alkene products $(\mathbf{2} \mathbf{i}-\mathbf{k})$ in Scheme 4 of the original publication was misattributed. The corrected structures are shown in Scheme 1.
A corrected version of Supporting Information File 1 is also part of this Correction. The new Supporting Information File 1 is the complete file with the corrections marked in yellow color.

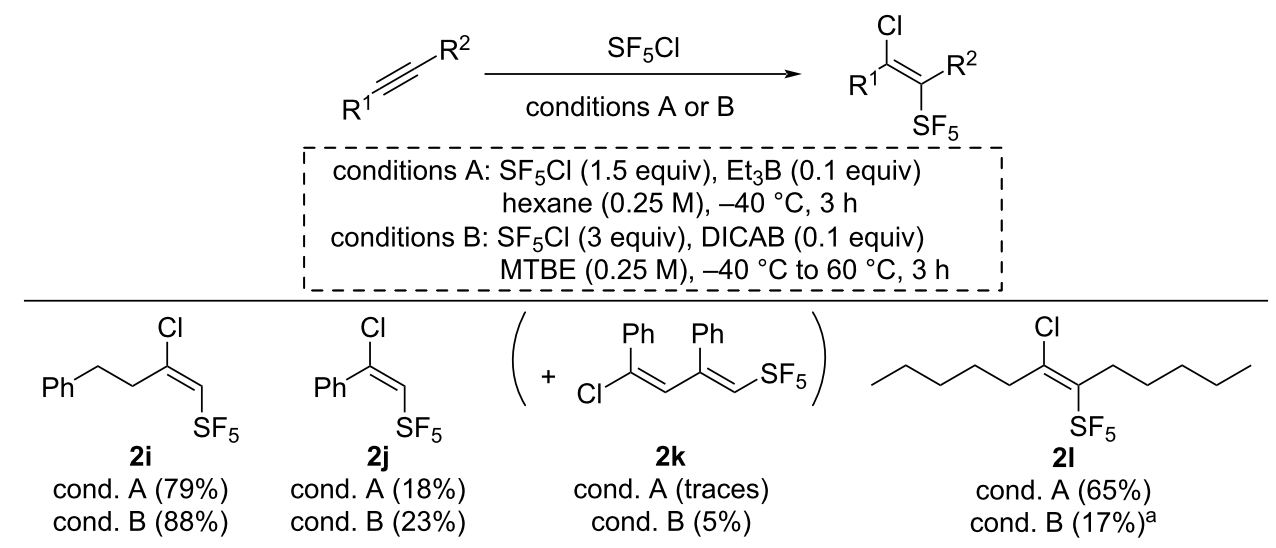




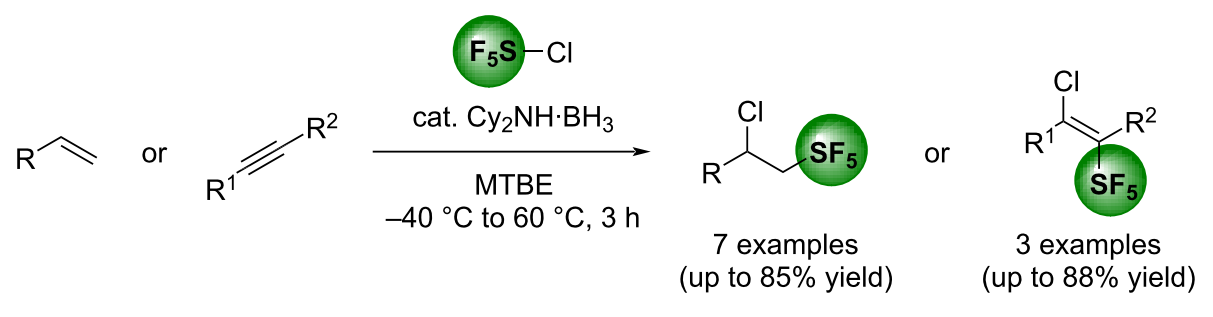

Scheme 2: Corrected graphical abstract of the original publication.

Finally, the Table of Content graphic was also corrected. The corrected version of the original graphical abstract is shown in Scheme 2.

We apologize for any inconvenience caused.

\section{Supporting Information}

\section{Supporting Information File 1}

General information, synthetic procedures, additional optimization results, NMR spectra for known compounds $\left({ }^{1} \mathrm{H},{ }^{19} \mathrm{~F}\right)$ and full characterization of all new compounds. [https://www.beilstein-journals.org/bjoc/content/ supplementary/1860-5397-17-120-S1.pdf]

\section{ORCID ${ }^{\circledR}$ iDs}

Laurent Chabaud - https://orcid.org/0000-0002-2590-8707

Jean-François Paquin - https://orcid.org/0000-0003-2412-3083

\section{License and Terms}

This is an Open Access article under the terms of the Creative Commons Attribution License (https://creativecommons.org/licenses/by/4.0). Please note that the reuse, redistribution and reproduction in particular requires that the author(s) and source are credited and that individual graphics may be subject to special legal provisions.

The license is subject to the Beilstein Journal of Organic

Chemistry terms and conditions:

(https://www.beilstein-journals.org/bjoc/terms)

The definitive version of this article is the electronic one which can be found at:

$\underline{\text { https://doi.org/10.3762/bjoc.17.120 }}$ 